\title{
Albanian Entrepreneurial Practices in Human Smuggling and Trafficking: On the Road to the United Kingdom via Brussels, 1995-2005
}

\author{
Johan Leman* and Stef Janssens*
}

\begin{abstract}
The authors studied the entrepreneurial culture among Albanian smugglers and traffickers using 43 Albanian judicial files in Belgium from 1995-2005. They analyse the niches that these "entrepreneurs" created as well as the way they invested profits. The authors also analyse the personal agency of the smuggled and trafficked clients, and practices that may help to explain the specific entrepreneurial culture. Short comparisons are made with other ethnic criminal groups engaged in similar activities during the same period in Belgium.
\end{abstract}

\section{INTRODUCTION}

For a considerable amount of time during the 1990s, Albania held an important position in human smuggling and trafficking routes (Hadjinjak, 2002). Originally, most illegally transported migrants brought from Albania went to Italy. Afterwards, they were joined en route by Kurds, Chinese, Iranians, Pakistanis, Bosnian Muslims, Macedonians, amongst others. According to the Italian authorities, between 500,000 and 1,000,000 undocumented migrants were smuggled from Albania to Italy in the 1990s, including approximately 100,000 Albanian women (Limanowska, 2002). Shortly afterwards, the United Kingdom appeared in the picture (Carletto, 2006).

Salt and Stein (1997) suggest that there are three phases in irregular migration processes, namely exit, transit, and entry. In each phase, particular services are offered. Operating within a similar logic, Van Amersfoort places emphasis on three important material and operational "intermediary structures" in the analysis of contemporary human smuggling that help to link the three phases with one another (Van Amersfoort, 1998: 15).

Using Albanian judicial files at disposition in Belgium concerning the period 1995-2005 for a research on Albanian entrepreneurship in trafficking, we examined in detail how some of these intermediary structures link the countries of exit, transit and entrance. Travel agencies

* Interculturalism, Migration and Minority Research Center, Faculty of Social Sciences, KU Leuven. 
or transport companies create transport links and deal with passport and visa issues. They may be involved solely in illegal activities or integrate their illegal activities into legal ones.

During the transit phase safe houses serve various purposes: as places to transfer money among collaborating organisations, for the removal of passports, or as places where those involved in the smuggling network would takeover shifts (Leman and Janssens, 2006: 237).

In some files, we can also see how former intelligence agents were involved either as network leaders or provided insider assistance. Following the collapse of communism in 1991, the Albanian security service Sigurimi was replaced by SHIK, i.e. the 'Shêrbimi Informativ Kombêta' or National Intelligence Service (CSD, 2002). Around one-third of the Sigurimi workforce, most of whom were officers, formed this new security service (CSD 2004), but a few former Sigurimi agents who had been dismissed offered their services to criminal organisations (Xhudo, 1996).

Entrepreneurship within Eastern European smuggling and trafficking is an under-researched subject area. A more thorough understanding of this issue would be of interest not just to scholars, but additionally to officials involved in the fight against these practices. For the latter, a more probing insight into both hidden financial investments that could potentially destabilise an economy, and also the human rights abuses that take place would be of great value.

\section{FIELD, RESEARCH TOPIC AND METHODOLOGY}

When comparing 43 Albanian files with 66 files of other ethnic provenance in the period 1995-2005, we discover well-established traditions that vary from one country to another, particularly in the early years. We chose to focus on the entrepreneurial culture of the Albanian criminal groups. Our objective is not to present certain characteristics as typical of the ethnic group, as we see historical and partly socio-cultural contexts that can differ greatly from one another. We therefore specifically examine Albanian entrepreneurial cultures that developed on the route between Brussels and England in human trafficking activities from 1995-2003, and in human smuggling from 1996-2005. The difference in time period between both groups of files is merely coincidental and not a factor to be taken into consideration. We compare 32 Albanian human trafficking files and 11 Albanian human smuggling files with files from other ethnic criminal groups in the same period. Regarding human trafficking, we make short comparisons between the 32 Albanian trafficking files and 30 other ones (namely 13 Bulgarian, five Russian, five Romanian and one Polish trafficking file, as well as six inter-ethnic trafficking files comprising Albanian, Bulgarian and Italian networks). For human smuggling, we compare 11 Albanian files with 36 others (namely 12 post-Soviet Eastern European, mostly Bulgarian, but also Romanian, Ukrainian and Russian, nine IndoPakistani, five Turkish, and ten Chinese human smuggling files). We gained access to these files through our work with human trafficking victims. We were able to study these judicial files in extenso. We keep the identities of those involved anonymous and focus exclusively on the elements of entrepreneurial culture.

During the period which we studied, one of the authors was the director of the Belgian federal office representing victims of human smuggling and trafficking in court (CGKR, 2001). The period of research was therefore determined by the timing of the author's directorship position. When a client gave his approval, the entire file was then made accessible to the author. Information pertaining to entrepreneurial cultures within human trafficking and smuggling was gathered from the aforementioned files. We looked at several different factors, including types of management utilized, methods of collaboration and financing, interaction with victims as well as information deemed anthropologically relevant. 
The proportion of ethnic criminal groups that we studied is not necessarily representative of Belgian human smuggling/trafficking files of that period. We chose specifically to focus on the Albanian files. There exists, therefore, a bias with regards to time, place, and accessibility to the files. Also important is the fact that the authors worked on materials added to the files by other professionals, mostly police officers. However, from interviews with the police and magistrates, as well as police analyses about the phenomenon of human smuggling in these files, we can ascertain that Albanian criminal groups were quite prominent in the period studied, and that the other non-Albanian networks that we will discuss were also very active in Belgium (mostly in the Brussels area).

The information available to us usually consisted of police investigations within the judicial files. It was complemented by interviews that we conducted with police officers about these criminal groups. The accuracy of the information corresponds accordingly with the accuracy of the police investigations themselves. Information about places of investment by the entrepreneurs was given primarily by imprisoned smugglers/traffickers, and therefore estimations of amounts of money are deduced by the authors from this given information. Information about the quality of the treatment of the clients was obtained through interviews of the clients conducted by police officers as well as wiretaps of conversations between the traffickers. Wiretap information and observations, combined with the study of the links between accused perpetrators with other judicial files, and information given by the Belgian administration and clients provided us with insight into the collaboration among the networks.

We consider that "court cases are the most reliable source for working out organizational principles of human smuggling" (Neske and Doomernik, 2006: 46; see also Pastore et al., 2006: 99). Our use of judicial files is compatible with this.

Our definitions of human trafficking and human smuggling are based on those given by Belgian law (voted 10 August 2005). We thus chose to use these Belgian definitions since the files were written in accordance with that particular legislative framework. These definitions, however, closely conform to those within UN Protocols. The UN defines human trafficking as bringing human beings from one country to another for "sexual exploitation, forced labour or services, slavery or practices similar to slavery, servitude or the removal of organs" (UN, 2000a: 3). Furthermore, "smuggling of migrants shall mean the procurement, in order to obtain, directly or indirectly, a financial or other material benefit, of the illegal entry of a person into a State party of which the person is not a national or permanent resident" (UN, 2000b: 3). Several studies have shown that human smuggling can readily degenerate into trafficking. There is sometimes a grey area between the two (Meese et al., 1998).

In addition to seeing themselves as victims, the clients interviewed also viewed themselves as "candidate migrants". This term thus seemed appropriate to refer to them in this article (see Agustin, 2003, 2006). While some trafficked women knew that they would become sex workers, most of them apparently did not envision the terrible conditions that they would have to face. Others had no knowledge whatsoever about what would happen to them.

We are aware that there may also be an important element of learning processes (Kenney, 1999) and levels of business development when comparing entrepreneurial cultures trans-ethnically, and that cultures are not fixed practices. This paper gives a picture of entrepreneurial cultures in human smuggling and trafficking among Albanian entrepreneurs during a particular time, on a precise and very important piece of the trafficking and smuggling route. We try to understand the ethno-cultural and entrepreneurial elements related to the practices of Albanian criminal groups at that time. Our intention is not to make a generalization about all Albanian entrepreneurial cultures, or cultures connected to human smuggling and trafficking in a broader sense. Time and space are clearly limiting factors to the selection of the files which all concern cases recognised as "smuggling" or "trafficking" by Belgian courts. 
The questions we wanted to find answers for were: 1) What niches and entrepreneurial cultures did the sentenced Albanian traffickers and smugglers develop? 2) What profits were made from human trafficking and smuggling among Albanians, and was there a general pattern in their investment of this money? 3) Did the Albanian traffickers and smugglers allow the candidate migrants space for personal agency? And 4) Are there any anthropologically recognisable practices at work, related to cultural perceptions of migration and family?

\section{ALBANIAN "HUMAN TRAFFICKING AND SMUGGLING” ENTREPRENEURSHIP}

In a Belgian immigration report about Albania, there was reference made to travel agencies that frequently collaborated with document and visa swindlers and malevolent lawyers and notaries at that time (Ministry of Home Affairs, 2001: 45). In Kosovo, travel agencies covered criminal smuggling organisations operating via the Balkan route (Morrison, 2000: 54-58). Albanian smuggling and trafficking files also show how corrupt officials were involved. In our Albanian files we found that corruption was present in more than one-third of the cases.

Our Albanian files covered three niches: 1) the trafficking of women (mostly for prostitution) oriented to most European countries, using small-scale transport as well as apartments and small hotels as safe houses under violent control, 2) large-scale operations with other ethnic criminal groups with central coordination in an Eastern European country, usually Albania, and 3) the control of a very important piece of the smuggling route from Brussels to England.

In one important case, for example, comprising three files - two purely Albanian ones and an inter-ethnic one - we find an illustration of all three niches. It concerns a single network, but with multiple segments. In one file from 2002-2003, covering the inter-ethnic segment of the network, 13,000 migrants were smuggled into the United Kingdom. In another Albanian file from the same period covering a segment of the same network, 1,000 migrants were traced in just a few months. Two leaders of the network were former Sigurimi agents who later also worked for SHIK until the Berisha period (1997). One of them had previously held a diplomatic passport. Some members appeared to be trained in counter-techniques against observation, which are taught by intelligence agencies. Another member of this network appeared in another file for supplying Lithuanian girls to Albanian pimps. The management adaptability of the inter-ethnic segment of the network can be seen in the way the safe houses were managed. A wiretapping operation revealed that the Albanian and Chinese smugglers responded to police action by moving the safe house from one city to another. In the interethnic segment, where a minimum of 13,000 migrants were smuggled, we see an international joint venture by Chinese, Indo-Pakistani and Albanian entrepreneurs. Whereas the entrepreneurial techniques in the Albanian networks remain clan related, they become more neutral and rational in the inter-ethnic segment, which led to subcontracting based on clear price agreements. What was clear was that the human trafficking culture in this Albanian file was based on (the potential use of) violence and absolute control.

A fundamental area of the Albanian entrepreneurship was travel agencies. One travel agency in Albania was used as the central cell of coordination in several large-scale smuggling cases. When it comes to the transport sector the tactics are quite different. Rather than dealing with the management of transport firms, they bribed individual truck drivers to organize the transportation of clients. This system does not appear to have been a large-scale, well-structured business but rather chaotic, small-scale networking initiatives.

One way in which the Albanians differed from the other groups studied was that they did not invest in the control of complex, large-scale routes but instead focused on small-scale 
businesses. They invested in regional monopolies that are either key sections along the smuggling route or are fundamental for the coordination in a trans-ethnic and trans-national approach. In the trafficking business they liked to keep things solely under their control, to the extent that it was possible. This approach enabled them to make very profitable deals. One example is the control over a section of the motorway between Brussels and the Belgian coast and over the embarkation of trucks of migrants to be smuggled into the United Kingdom. From the end of the 1990s until 2005, the Albanian human smugglers in Belgium specialised precisely in this small part of the smuggling route. This approach enabled them to have a specialisation in a limited but very important niche of the market. However, it is quite possible that another ethnic criminal group, such as the Indians, for example, could take over a similar strategic control of the Brussels to England route in the future. From 2005 onwards, due to increased interventions by the police on Belgian highways, the Albanians began to lose their privileged position in this section of the route between Brussels and England. It did not mean, however, that they lost control over other sectors of their multiple businesses.

\section{THE PRACTICES OF THE NON-ALBANIAN GROUPS}

When comparing the Albanian business practices with those of the Russians, we can conclude that the latter were more structurally developed, while the Russians set up firms with a mix of legal and illegal activities. Some Russian agencies offered travelling and employment opportunities and dealt with legal as well as illegal jobs in the West. From time to time they also organized human trafficking and prostitution. In the Bulgarian files, we see how travel agencies and bus companies had a very good understanding with employees and high officials in some Western European embassies in Bulgaria and very easily obtained the required tourist visas for fake tourists. They also specialised in transport, mostly to Schengen countries and to a lesser extent, the United Kingdom. This explains why they did not need to make agreements with the Albanians. For the Bulgarians and the Russians, involvement with the Albanians concerned only human trafficking and prostitution, not human smuggling.

This was different from the Indo-Pakistani and Chinese networks in our files. The clients of the Indo-Pakistanis wanted to reach the communities of their compatriots in the United Kingdom. The same is true for the Chinese and partly also for the Turks. Among these migrants there was a common belief that it was easier to find a job in the United Kingdom than in mainland Europe and that it was also easier to hide within their ethnic community. Almost all these networks had to make agreements with the Albanians since they smuggled a category of migrants whose final destination was the United Kingdom. There was no reason for the Indo-Pakistani, the Turkish and Chinese organisations involved in the smuggling of illegal economic migrations to question the expertise and monopoly of the Albanians regarding the niches that they controlled, at least for the Belgian route. The price to be paid to the Albanians became part of the total amount that the economic migrant had to pay the contact person responsible for the whole journey. Generally two prices were proposed: an amount with and an amount without successful outcome commitment.

Networks that worked quite differently, for example, were the Turkish criminal networks. Again, this discussion only involves the networks active in Belgium during the period of our research. Within these Turkish criminal networks we find a high learning capacity (Kenney, 1999). The Turkish networks were extremely innovative and flexible. Internationally, they are very well organized and use various strategies and partners. They also use maps of alternative smuggling routes, and small harbours or airports where there is only minimal security. They use a contingent of well-paid truck drivers who can easily earn up to 1,000 Euros for a single 
trip, potentially earning them a monthly income of 15,000 Euros. These drivers are frequently placed on new roads and alternate their hired trucks in an attempt to be inconspicuous. These types of transportations are mostly those with a successful outcome commitment, meaning double the price for the migrant. In the cases we studied, the Turkish networks were only interested in Albanian support during the short section of the route between Brussels and the United Kingdom.

During the period of our research, the first files of Georgians and their trafficking and smuggling business on the Brussels-UK route were still being completed and could not therefore be studied. In 2008, Georgian criminals appeared to be the last "newcomers" in Belgium with interest in human trafficking and smuggling.

\section{PRACTICES WITHIN THE INTERNATIONAL COLLABORATIONS}

The recruitment of candidate migrants by partner organisations did not interest the Albanian networks. The Turks focused principally on Kurdish candidate migrants and on other migrants whose trip had been interrupted in Turkey for one reason or another, mostly financial. The Indo-Pakistanis focused on migrants from the Punjab and surrounding countries. The Chinese looked for candidate migrants from the Zhejiang region of China. Aside from possibilities for other smuggling opportunities (e.g., drugs, arms, etc.), activities such as the management of safe houses and transit hotels, infiltration or management of transport firms, corruption of police officers and officials in the countries of provenance, did not interest the Albanians.

When distances were large or when the final section of the route was not one that the Albanian network controlled, an international coordination centre was set up for subcontracting staff. Whereas within their group it is family and clan structures that bind them, with the other criminal groups cooperation is based on contractual agreements. It corresponds to network agreements both on the basis of mutual reputation (Moerland and Boerman, 1999; Raub, 1997; Von Lampe and Johansen, 2004; Weerman and Kleemans, 2002) and of the existing establishment of territory control (Von Lampe and Johanssen, 2004: 106). In such a case, their "ethics" are business ethics where agreements are agreements and a word is a word, and where everyone is free to do what he wants within his own domain.

Comparing the Albanian strategies with those used by other ethnic networks in our files we see that Albanian entrepreneurs are not particularly inventive, either in the elaboration of their business or in their contact with outside groups. But they are efficient in the way they work. The Indo-Pakistani criminal organisations, for example, almost always opt for collaboration with other networks such as the Albanian ones, but retain control over their clients. Migrants are under obligation to the Indo-Pakistani smuggling network only, and not to the Albanian networks involved. After arrival in the United Kingdom, the migrant is under obligation to inform only the original contact at the Indo-Pakistani network of their successful transportation. This is not a problem for the Albanians. Following this, the Albanian networks receive 1,000 Euros per person per successful transportation directly from the Indo-Pakistani network.

\section{WHAT ABOUT PROFITS?}

Among the Albanian cases there are no indications to suggest that their system of investment of profits from human trafficking are any different from those of human smuggling. In both cases, however, the place of investment is easier to ascertain than the amount of profit. Regarding profits, we can only make estimations. Hence in this area, much remains unknown. 
Cases of "lover boy" recruitment represent one-third of our Albanian trafficking files. This is when a man pretends to be a lover to force girls into prostitution. There are no recruitment costs. The girl even has to pay a penalty if she becomes unfaithful to her lover boy. From one of our files we learned that, after an attempt to escape, one girl was obliged to pay a penalty of 7,500 euros. After recruitment the Albanian criminal groups focus directly on buying and selling girls (in 16 trafficking files) for between 1,000 and 3,000 Euros. Maximisation of profits is the first objective, making deals between the pimp and bar owners on a $50 / 50$ basis. In two files from 1999, girls were hired out for between 1,750 and 2,500 Euros a month. This meant that the sex workers had to work shifts of 12 to 18 hours per day, and their clients paid 25 Euros for ten minutes. The files reveal how these girls earned a minimum of 250-1,000 Euros per day, which was all to be given to the pimp. In one file about a largescale network the profits per girl were 7,500 Euros a month.

In nineteen Albanian human trafficking files, the pimps retained enough money to live a luxurious lifestyle (Williams, 2006: 7) and sent the rest of the profits to the clan in Albania. One case showed how an Albanian network that abducted and sold girls sent 100,000 Euros to its clan. In another case of Albanian brothers, 12,500 Euros was sent back to their family in Albania after just one and a half months of work.

In smuggling files prices are quite different. Some parts of the route are more expensive than others. For example, the route from Brussels to the United Kingdom is very expensive. Without a successful outcome commitment this ultimate piece in the route may cost 2,000 Euros, and with a commitment it could be 6,000 Euros. The money earned through smuggling a migrant client is much lower than with a client who is trafficked into prostitution. At the same time, however, the business concerns more clients and the risks when captured are minor in comparison. From the files we learn that besides money transfers to Albania, smugglers often invest in importing cars from Western Europe to south-eastern Europe.

When these Albanian files are compared with others from the same period, we see how post-Soviet (Russian and Bulgarian) organizations used travel agencies most of the time, in combination with employment agencies. They tried to control both. Here also there were no recruitment costs. In the case of trafficking, the organized internal structure is non-clan based but formed "on the basis of cells or small units (...) through a network" (Shelley, 2003: 242). It avoids the use of physical violence as it wants to safeguard its human merchandise for as long as possible. The post-Soviet networks in our sample often anticipated their migrants (even trafficked women) needing legal support, and thus charged them more for this. In one file the trafficked women paid 7,500 Euros per month for services prior to being trafficked, as well as for those needed in the country of destination.

Post-Soviet networks diversify in their investments. A lot of money is invested outside of the post-Soviet area, some in typical speculative activities or in coastal areas in the countries of provenance. Money laundering is done through travel agencies, transport companies, the retail industry and even the horticulture sector. There is more diversification in the management of profits than among Albanian clans.

Another interesting comparison is the investment of profits of Indo-Pakistani smuggling networks using the Brussels-to-UK route. In one of our files, the police researchers made an estimation of the profits acquired by one Indo-Pakistani network. In a 24 -week period, with a minimum profit of 1,000 Euros per migrant and based on the work of one driver making one transport per night three nights a week, the researchers calculated a total net profit for the network of 720,000 Euros. For money transfers into the country of provenance, Indo-Pakistani networks often used the Hawala system, or Western Union. The Hawala system means that the money is transferred without any bank activity. 
A hawaladar from country A receives funds in one currency from a customer in country A and in return gives the customer in country A code for authentication purposes. He then instructs his country B correspondent to deliver an equivalent amount in the local currency to a designated beneficiary, who needs to disclose the code to receive the funds. The hawaladar in country A can be remunerated by charging a fee or through an exchange rate spread". (El Qorchi 2002)

This is done via telephone or night shops. In the countries of provenance profits are invested in the tourist industry and in the import-export sector. In European countries, it was usually Internet cafes, night shops, petrol stations or travel agencies that were used for money laundering. In one case an Indo-Pakistani network invested in Internet cafes and night shops in the Netherlands, France, Belgium, Poland and Russia. In some cases, money was also given to an Islamist group.

From a telephone recording of a conversation between Turkish smugglers, a researcher heard how in one Turkish network one individual had earned 100,000 Euros in just two or three important transports. When it comes to investment of profits, Turkish networks behave more or less in a similar way to the other non-Albanian groups, except for the Hawala system. Money transfers as well as money couriers are used. Most of all, it is the transport sector that holds their major interest. In one Turkish case, they established transport firms in Germany, the Netherlands, Austria and the United Kingdom.

Finally, the Chinese also show a dual interest regarding investments. In China, they were interested in the import-export business, but also in the wholesale trade of goods such as textiles to and from Italy, Spain, France and Belgium, among others. In Europe, there was an interest in restaurants, and some cases showed an interest in massage parlours as a way to push women into prostitution through debt bondage, as well as the purchase of real estate in the West.

From all these files, we learn that the Albanian criminal networks are the ones that diversify the least, and in this sense they are the least inventive. What is clear from their strategy is their huge respect for the family, the clan and its structure.

\section{PERSONAL AGENCY AMONG CANDIDATE MIGRANTS}

In all the Albanian smuggling cases it appears that the clients in Belgium are economic migrants. In some cases, the family property would be invested in financing the emigration of just one family member. Although the country of destination par excellence is the United Kingdom, many migrants remained in the Mediterranean region. One reason for leaving mainland Europe was that it was possible to find a job in the United Kingdom without ID documents at that time. Very often we see how economic migrants divide their trip into different parts before arriving in the United Kingdom. For those being trafficked there is often also an element of migration, namely as sex workers, which they may not know about beforehand.

In trafficking, Albanians often use "lover boy" techniques to push girls into prostitution. Waldmann (2001) explained how the perversion of the Kanun morality in these cases led to a complete devaluation of the position of the woman, a problem that still exists among criminal groups and clans more than elsewhere (Arsovska, 2006a, 2006b). The Kanun morality is supported by a friend/enemy discourse and "an exaggerated sense of honour and the selfunderstanding of an organization under oath" (Waldmann, 2001: 441). In such a situation, there is not much room left for a woman's personal agency. 
As far as smuggling activities are concerned, the attitude is different. The position of the women is not comparable with that of trafficked women, and when entering into a partnership with other ethnic organisations, they accept that it is the responsibility of the migrant and their family to cooperate with each network. If a network is violent, it is an issue between the people concerned and not between the entrepreneurs of the other collaborating networks. Albanians show respect for one another's way of working. They do not criticise another's behaviour vis-à-vis migrants. As far as Albanians are concerned, there is space for agency for the smuggled migrants. Yet on crucial routes they enforce discipline and will, at times, resort to violence to do so.

When comparing the personal agency among clients of Albanian networks with the situation in other ethnic networks, we see how the post-Soviet networks allow their clients more freedom, treating them rather like tourists the majority of the time.

From the stories of the migrants from India, Pakistan and Afghanistan, it appears that they are very often obliged to pay their smugglers additional unforeseen costs during the trip. Various procedures may be followed regarding payment. Sometimes the total amount is already paid in the country of provenance, seen as a family investment that will be repaid in the coming years through money made in the West. One of the migrants told how he paid 17,500 Euros in the Punjab before leaving. Another migrant paid for a journey as far as Brussels, where he sought employment to pay the final Brussels to England part of the journey using the Albanian route.

For each journey before arrival in Brussels, the Indo-Pakistani networks transported ten to 15 people per truck. At the various stops along the way the migrants were transferred to safe houses which consisted of single-room apartments where the entire group waited together to continue their trip. In these safe houses they would be watched over by a member of the network who kept in contact with the organisation via a mobile phone. The migrants were not locked in the room, but the collective pressure to remain inside was such that it became impossible to leave the house. In cases of police interception, migrants would return to the safe house hoping to be able to then continue their journey again.

Among Chinese entrepreneurs, there is a practice that seems to be frequently used which limits the agency of the client, namely "debt bondage". From the outset the entrepreneurs propose a system to deal with the extortionate amount of money that they demand, as they understand that it is too much for many candidate clients. The prices vary between 12,500 and 25,000 Euros which is all-inclusive (fake documents, accommodation in safe houses, etc.). An agreement may be proposed in which part of the price is paid before leaving China and then a supplementary payment made by working during the trip. This does not mean that the calculation of the price is a strictly objective affair, but is an opportunity for the organizer to earn even more money. In some cases, Chinese entrepreneurs would require contracts from clients, pledging fidelity to the smugglers and agreement to work for them for low wages for a certain length of time. The smugglers would exploit cultural ideas of familial loyalty in such contracts.

\section{CULTURAL ELEMENTS FOUND IN ALBANIAN "SMUGGLING AND TRAFFICKING" ENTREPRENEURSHIP}

As with many other people around the Mediterranean region, Albanians have a long history of migration (Carletto, 2006; Vullnetari, 2007). During the Ottoman period there was an important tradition called kurbet, meaning "journeying far in order to support the family back home" (King, 2005: 134). Kurbet was something special. A migrant who was called kurbettli, was someone who was considered courageous but at the same time it had the 
connotation of being exploited, a feeling of loss (Mai and Schwandner-Sievers, 2003: 945). Migration was perceived as a male issue: "this historic framing of Albanian migration through the culture of kurbet has important implications for the way the phenomenology of post-communist migration is experienced and interpreted - above all by migrants themselves" (King and Vullnetari, 2003: 18).

Migration can be part of the economic strategy of a family (Nicholson, 2004: 878). It concerns "the internal family nature" of financial regulations (Nicholson, 2001: 40). Albanians abroad continue to see themselves as part of the extended family in Albania. As a consequence, there is a permanent financial stream from outside Albania to the areas of provenance (Kaser, 2000: 55) for building or renovating homes, etc. These money transfers are an important tool "to secure the respect of the extended family by allowing them to witness important events (...) These events are hugely important because they mark the history and future of the family, and its status and honour" (King, Dalipai, and Mai, 2006: 425-426). Some small firms are also started up with the aid of this financing (Nicholson, 2004: 881882).

The "internal family nature" of financial regulations and the financial stream from outside Albania to the areas of provenance, as well as the profound meaning of kurbet as "journeying far" for family support do not explain the existence of "smuggling and trafficking practices", but clearly help to explain the way the smuggling business and its investments are organized.

We have already referred to perverting the Kanun ideology to explain the lack of agency for trafficked women. The same perverted ideology may also explain the rigidity of the power system inside criminal networks. For the Kanun, political authority is distributed in a tribal structure: the fis $(i)$, which follows segmentary principles. The clan segment in a business has the head of the segment as its political leader. The segment members themselves accept the power logics of the segment as the most natural structure of life (habitus). For criminals involved in it, perversions of the Kanun have become a habitus (Voell 2003: 92-93). This explains why in some disputes among Albanian criminals only the head of the clan has the authority to resolve them.

\section{CONCLUSIVE REMARKS}

For our period of research (1995-2005) we discovered that the Albanian criminal groups made use of travel agencies as coordinating cells, but did not create other firms for other stages in the intermediary structures. This is different from the strategy followed by Russian and Bulgarian entrepreneurs in our files, for example. In the countries of transit the Albanians worked mostly through strategies of infiltration in legal businesses for their smuggling, and through agreements with bar owners for the organisation of prostitution. As far as other ethnic criminal groups were concerned, they left the control of safe houses to them. The Albanian human smuggling and trafficking business seems to be small in scale and not hierarchically organized, more or less chaotic most of the time and using a large amount of violence when it was felt needed, giving these entrepreneurs a terrifying reputation.

The niches that the Albanian entrepreneurs fill in their business are threefold: 1) a human trafficking business using prostitution, led by an entrepreneurial culture that is profoundly determined by a perverted Kanun ideology in their relations with women, in terms of authority and power; 2) a smuggling business that has a closed family- or clan-based structure and shows a mostly limited and only reactive adaptation capacity; and 3) a partnership through precise and rather restrained but important "rational" engagements in broader inter-ethnic 
and transnational large-scale smuggling networks. They prefer well-circumscribed businesses that they can control with smaller family- or clan-based groups.

The investments of profits are oriented mostly to the areas of provenance and family affairs, sometimes in small firms in their home region. Some also invested in importing cars from the West to Albania. In some cases, political parties also benefited from trafficking and smuggling, for example the Kosovo Liberation Army in Kosovo and Berisha's Party in Albania. There was large diversification in the investment of profits by the non-Albanian criminal networks (Black et al., 2001; Carter, 1997), but not for the Albanians during the period studied. Since 2005 there has been growing Albanian criminal entrepreneurship in other countries such as Italy and Germany. It is predicted that this will lead to more investment outside Albania and greater diversification.

People smuggled by the Albanians often viewed themselves as migrants, even in light of the fact that many of them were trafficked (e.g., sex workers). Some, on the other hand, were simply victims. The idea of kurbet as migration under harsh conditions for family interests is omnipresent in the minds of all Albanians concerned in this business, the entrepreneurs and clients alike.

We have already noted that from 2005 onwards, due to increased police interventions on Belgian motorways, the Albanians lost their privileged position in the human smuggling business between Brussels and England. From a press statement in October 2008, when this study was completed, we learned that the Belgian police had infiltrated an Indian Punjabi network that transported many hundreds of undocumented Sikh migrants from Brussels to England in 2006-2008. The name of the police operation was Sunset. The techniques that the Indian network used were similar to the ones that the Albanian network used before, but the prices were different. The cost of the journey from India to Belgium was up to 20,000 Euros, and from Brussels to the United Kingdom as little as 1,500 Euros without a successful outcome commitment and 4,000 Euros with one. This decrease in price was probably due to there no longer being Albanian middlemen to pay. The trucks with smuggled migrants started at sunset from parking spots along the motorway, a strategy adopted from Albanian techniques.

Among the networks in our files the Albanians were the most rigid, most conservative and least flexible in their entrepreneurship due to their clan culture. Still, this does not mean that they were unable to work rationally and openly in their partnerships with other ethnic groups. It also does not mean that they will continue this particular way of working in future years.

From our files, we can clearly see the diversity of entrepreneurial cultures existent both within the groups themselves, and in their collaborations with other groups. Investment behaviour, attitudes vis-a-vis clients, and niches may be markedly different and may also change over time. When dealing with human trafficking and smuggling, we first need to clarify what we are really fighting against: the investment of illegal profits? Illegal migration? Or criminal networking? Also to be kept in mind is the diversity in strategies used by the networks, even if there seem to be some characteristics related to the past practices and cultural traditions of each group.

Keeping this diversity in mind, it is evident that smuggling networks must be structurally dismantled, so that they cannot simply be rebuilt. Research should not only focus on the practitioners involved in smuggling and trafficking activities who may be easily replaced in the short term, but should instead be oriented on the coordinating key persons and on structuring factors such as firms from the transport and tourist sectors, night shops, and some restaurants, which can play both functional and laundering roles. To combat these networks effectively, it is necessary to analyse the financial structure and to fight the practice of money laundering. It is only in this way that large-scale smuggling networks with all their various branches can be dismantled at the roots. Some clear management steps should be undertaken 
so that judicial officials and police are able to obtain the needed means to execute financial analyses. International collaboration should be carried out to facilitate in practice the confiscation of criminal benefits in the countries of provenance, as well as in some countries of transit and investment. Doing all this, which requires several initiatives to be taken at political and international levels, is the only way to successfully combat these large-scale networks.

\section{REFERENCES}

Agustin, L.

2003 "The difference borders make: (il)legality, migration and trafficking in Italy among Eastern European women in prostitution", in D.D. Ahmed and et al (Eds.), Uprootings/Regroundings: Questions of Home and Migration, Berg, Oxford: 251-272.

2006 "The disappearing of a migration category: migrants who sell sex", Journal of Ethnic and Migration Studies, 32: 29-47.

Arsovska, J.

2006a "Understanding a 'culture of violence and crime': the Kanun of Lek Dukagjini and the rise of the Albanian sexual-slavery rackets", European Journal of Crime, Criminal Law and Criminal Justice, 14: 161-184.

2006b "Gender-based subordination and trafficking of women in ethnic based context. The upward revaluation of the Kanun morality", Kolor, Journal on Moving Communities, 6(1): $3-19$.

Black, C., T. Van der Beken, B. Frans and M. Paternotte

2001 Reporting on Organised Crime: A Shift from Description to Explanation in the Belgian Annual Report on Organised Crime, Maklu, Antwerp.

Carletto, C., B. Davis, M. Stampini and A. Zezza

2006 "A country on the move: international migration in post-communist Albania", International Migration Review, 40(4): 767-785.

Carter, D.

1997 "Emerging trends in entrepreneurial crime", in Understanding Organised Crime in Global Perspective. A Reader, Sage Publications, London: 139-140.

CGKR (Center for Equal Opportunities, Fight Against Racism)

2001 Jaarverslag 2000, Beeldvorming van de Mensenhandel en Analyse van de Rechtspraak, CGKR, Brussels.

CSD (Center for the Study of Democracy)

2002 Smuggling in Southeast Europe, Center for the Study of Democracy, Sofia.

2004 Partners in Crime. The Risks of Symbiosis Between the Security Sector and Organized Crime in Southeast Europe, CSD, Sofia.

El-Qorchi, M.

2002 "Hawala", Finance and Development, 39 (4), http://www.gdrc.org/icm/hawala.html.

Hadjinjak, M.

2002 Smuggling in Southeast Europe. The Yogoslav Wars and the Development of Regional Criminal Networks in the Balkans, CSD, Sofia.

Kaser, K.

2000 "The history of the family in the $20^{\text {th }}$ century: a first profile", Ethnologia Balkanica, 4: 45-57.

Kenney, M.

1999 "When criminals out-smart the state: understanding the learning capacity of Columbian drug trafficking organisation", Transnational Organized Crime, 5(1 Spring): 97-119.

King, R.

2005 "Albania as a laboratory for the study of migration and development", Journal of Southern Europe and the Balkans, 7(2): 133-155.

King, R., and J. Vullnetari

2003 "Migration and development in Albania", Working Paper, Sussex Centre for Migration Resarch, Sussex, http://www.migrationondrc.org/publications/working_papers/WP-C5.pdf. 
King, R., M. Dalipaj, and N. Mai

2006 "Gendering migration and remittances: evidence from London and Northern Albania", Population, Space and Place, 12: 409-434.

Leman, J., and S. Janssens

2006 "An analysis of some highly-structured networks of human smuggling and trafficking from Albania and Bulgaria to Belgium”, Migracijske i etnicke teme, 22(3): 231-245.

Limanowska, B.

2002 Trafficking in Human Beings in South Eastern Europe. Current Situation and Responses to Trafficking in Human Beings in Albania, Bosnia and Herzegovina, Bulgaria, Croatia, the Federal Republic of Yugoslavia, the Former Yugoslav Republic of Macedonia, Moldova and Romania, UNICEF/UNCHR/Osce-Odihr, Belgrade/Warsaw.

Mai, N., and S. Schwandner-Sievers

2003 "Albanian migration and new transnationalisms", Journal of Ethnic and Migration Studies, 29(6): 937-948.

Meese, J., K. Van Impe and S. Vanheste

1998 Multidisciplinary Research on the Phenomenon of Trafficking in Human Beings from an International and National Perspective. A Pilot Study with Poland and Hungary, University of Ghent, Ghent.

Ministry of Home Affairs

2001 Strategic Analysis on Emigration in Albania. Report, General Direction of the Foreigners Office, Belgian Liaison Officer Tirana, Brussels, December.

Moerland, H., and F. Boerman

1999 Georganiseerde Misdaad en Betrokkenheid van Bedrijven, Gouda Quint, Kluwer Rechtswetenschappen, Deventer, Antwerp.

Morrison, J.

2000 The Trafficking and Smuggling of Refugees. The End Game in European Asylum Policy, UNHCR's Policy Research Unit, Centre for Documentation, UNHCR, Geneva.

Neske, M., and J. Doomernik

2006 "Comparing notes: perspectives on human smuggling in Austria, Germany, Italy, and the Netherlands", International Migration, 44: 9-58.

Nicholson, B.

2001 "From migrant to micro-entrepreneur: do-it-yoiurself development in Albania", South-East Europe Review for Labour and Social Affairs, 3: 39-41.

2004 'The tractor, the shop and the filling station: work migration as self-help development in Albania", Europe-Asia Studies, 56(6): 877-890.

Pastore, F., P. Monzini, and G. Sciortino

2006 "Schengen's soft underbelly? Irregular migration and human smuggling across land and sea borders to Italy", International Migration, 44: 95-119.

Raub, W.

1997 "Samenwerking in duurzame relaties en sociale cohesie", in Kleemans E.R., Brienen M.E.I and H.G. vande Bunt (2002). Georganiseerde criminaliteit in Nederland. Utrecht: University of Utrecht: http://www.fss.uu.nl/soc/iscore/papers/paper115.pdf (16.08.2010)

Salt, J., and J. Stein

1997 "Migration as a business: the case of trafficking", International Migration, 35(4): 467-494.

Shelley, L.

2003 "The trade in people in and from the former Soviet Union", Crime, Law and Social Change, 40: 231-249.

UN

2000a Protocol to Prevent, Suppress and Punish Trafficking in Persons, Especially Women and Children, Supplementing the United Nations Convention against Transnational Organized Crime, United Nations, Palermo.

2000b Protocol Against the Smuggling of Migrants by Land, Sea and Air, Supplementing the United Nations Convention Against Transnational Organized Crime, United Nations, Vienna. 
Van Amersfoort, $\mathrm{H}$.

1998 "An analytical framework for migration processes and interventions", H. Van Amersfoort and J. Doomernik (Eds.)., International Migration: Processes and Interventions. Het Spinhuis, Amsterdam.

Voell, S.

2003 "The Kanun in the city. Albanian customary law as a habitus and its persistence in the suburb of Tirana, Bathore", Anthropos, 98: 85-101.

Von Lampe, K., and P.O. Johanssen

2004 "Criminal networks and trust: on the importance of expectations and loyal behaviour in criminal relations", in S. Nevala and K. Aromaa (Eds.)., Organised Crime, Trafficking, Drugs, selected paper presented at the Annual Conference of the European Society of Criminology. Helsinki 2003, Helsinki, HEUN: 102-113.

Vullnetari, J.

2007 "Albanian migration and development: state of the art review", IMISCOE Working Paper, $\mathrm{N}^{\circ}$ 18, Amsterdam: IMISCOE, http://www.imiscoe.org/publications/workingpapers/documents/ Albanianmigration.pdf.

Waldmann, P.

2001 "Revenge without rules: on the renaissance of an archaic motif of violence", Studies in Confict and Terrorism, 24: 435-450.

Weerman, F., and E. Kleemans

2002 "Criminele groepen en samenwerkingsverbanden. Een overzicht", Tijdschrift voor Criminologie, 44(2): 114-127.

Williams, P.

2006 "Trafficking in women: Markets, networks and organized crime", draft paper presented at the Joint Area Centers Annual Symposium: Criminal trafficking and slavery: The Dark Side of Global and Regional Migration, University of Illinois at Urbana-Champaign, 23-25

Xhudo, G. February

1996 "Men of purpose: the growth of the Albanian Criminal Activity", Frank Cass Journal, 2(1): $1-20$. 